\title{
12 WEEDING OUT SPURIOUS ETYMOLOGIES: TOPONYMS ON THE ADELAIDE PLAINS
}

Rob Amery

\section{ETYMOLOGY OF KAURNA NAMES'}

The etymology of Kaurna placenames is often very difficult to determine. With the passage of more than 160 years since colonisation and several generations since the death of the last fluent Kaurna speakers, it is difficult to be certain about anything. Folk etymology is rampant. About $60^{2}$ different Kaurna placenames are recorded in the vocabulary sources. Teichelmann and Schürmann (1840) (henceforth referred to as T\&S), Williams (1840), Piesse (1840), Wyatt (1879) and Black (1920) all recorded Kaurna placenames.

Apart from the recognised sources of Kaurna language, placenames are recorded on a variety of maps. They appear in journals, government records, local histories, newspaper articles and especially in letters to the editor over the years. Others may be preserved in property names. ${ }^{3}$ Much of this material has been collated and published in several popular books on South Australian placenames, notably Praite and Tolley (1970), Manning (1986) and Cockburn $(1908 ; 1984 ; 1990)$.

Abbreviations used in this paper are: LOC locative; PL plural.

2 This is a far cry from the two to three thousand placenames known by any given adult in the Wik region of Cape York as discussed by Sutton (this volume), indicating the extent of language loss in the Adelaide area.

3 It should be noted, however, that many property names of apparent or obvious Aboriginal origins are drawn from other regions and other languages.

L. Hercus, F. Hodges and J. Simpson, eds, The Land is a Map: placenames of Indigenous origin in Australia, 165-180. Canberra: Pandanus Books in association with Pacific Linguistics, 2002.

(c) Rob Amery 


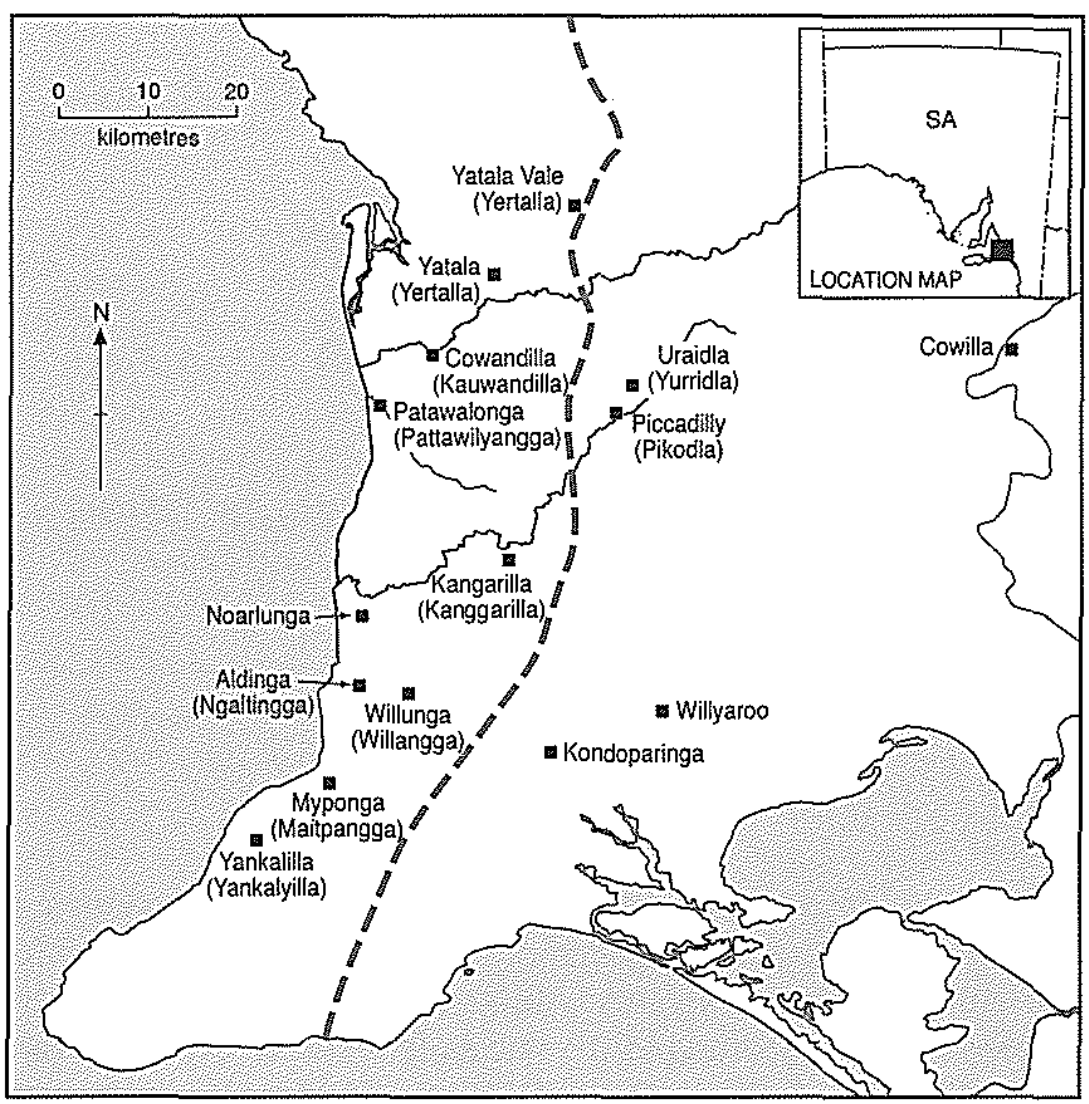

Map 1: Placenames of Aboriginal origin on the Adelaide Plains

Nineteenth-century sources on the Kaurna language, with the exception of Wyatt's (1879:5) explanation of Yurre illa 'two ears' and T\&S's observation that Noarlunga is derived from nurlo 'corner' (discussed later), did not try to provide etymologies for placenames on the Adelaide Plains. Black (1920) does attempt to do this for the 11 placenames he records, but often this is simply on the basis of T\&S. However, in the case of Ngangkipari (=Onkaparinga) he does appeal to his source, Ivaritji, for an explanation. He notes in the case of Pattawilya that Ivaritji was unable to explain the name, but on the basis of T\&S he ascribes the meaning 'gumtree foliage' to the name. We are left with the fact that, in almost all cases, meanings ascribed to placenames of Indigenous origins in the Adelaide area have been the result of speculation on the part of Black, Tindale, Webb and numerous others, including myself.

In some cases, such as Witongga 'The Reedbeds' in the Fulham area, the meaning is quite apparent. The word for 'reed' is wito and reeds are prolific in that locality. So there is little doubt that 'reed place' is in fact its rightful meaning and no competing etymology has been noted in the sources. In other cases, the meaning is not so readily apparent.

The popular placename books include some fanciful etymologies. In many cases we can say little about the true etymologies of these names, though we can use a knowledge of linguistics to call into question or exclude certain suggestions. A distinction needs to be

4 This is one of the few cases where the English name, The Reedbeds, is a translation (at least in part) of the Kaurna name. 
drawn between literal and connotative meaning, the difference between say wirra literally 'forest', though the connotative meaning might be 'hunting ground' or 'good country' or even 'wild', 'rugged' or 'untamed' depending on one's cultural background. The longer and more florid the description is, the less likely it is a literal meaning of the placename, though we cannot discount the possibility that it may be related in some way to the particular name through connotative or affective meanings, or perhaps by a story linked to the place. For instance, the Kaurna name for Morphett Vale is Parnanga, from parna 'autumn star' + -ngga 'LOC'. Therefore, Parnanga literally means 'autumn star place'. We do not know the story behind Parnanga, but from what we know of Kaurna cosmology, it is likely that Parnanga is the place from where the Ancestral Being Parna ascended into the heavens, or where he or she performed some other feat. Manning (1986:141) says it means 'autumn rain', in which case it is a connotative meaning.

Consider the following additional examples:

\subsection{Aldinga}

T\&S record the name as Ngalti-ngga, yet do not provide a vocabulary entry for ngalti. Manning (1986:3) notes that various meanings have been suggested for Aldinga, including 'much water'; 'good place for meat'; 'open wide plain'; and 'tree district'. In addition, Cockburn (1990:7) adds 'battle or burial ground'. None of the meanings noted by Manning or Cockburn make any sense in terms of the Kaurna words documented in the historical sources.

Now the suffix - ngga could be translated as 'place', and ngalti almost certainly consists of a single morpheme. Yet a number of the etymologies above suggest that a compound would be required to encode the notions. It could not possibly literally mean 'good place for meat', even though historical sources suggest that the Aldinga area was used as a kind of 'fattening paddock', because that would require at least two morphemes in addition to the -ngga suffix. Furthermore, the known Kaurna words for meat (paru), water (kauwe), plain (womma) etc. bear no resemblance whatsoever to ngalti.

Perhaps there was no meaning for Aldinga in the minds of Kaurna people alive back in the 1830s. Ngaltingga could have been just a name with no known meaning, just as Indulkana is just a name for Pitjantjatjara/Yankunytjatjara people today. If Aldinga had meant something, there is a good possibility that T\&S would have listed ngalti in their vocabulary, after having noted and listed the placename Ngalti-ngga.

\subsection{Willyaroo}

Willyaroo, close to Strathalbyn and a little to the east of Kaurna territory, is said by both Cockburn (1990:240) and Manning (1986:229) to mean 'to invoke a good harvest', though Praite and Tolley (1970:195) say it means 'scrubby plain'. Wilyaru is given by T\&S as 'one who has gone through all the initiatory ceremonies; a fully grown-up man'. Wilyaru also appears in Hercus's (1992) Nukunu dictionary as 'name of the final stage of initiation involving cicatrization' and in other languages to the north. Similar words are not found in Ngarrindjeri (Meyer 1843; Taplin 1879) or Ngayawang (Moorhouse 1846).

The meaning 'to invoke a good harvest' is most unlikely. It does not sound like the kind of notion encoded within an Indigenous language and in any case would require several 
morphemes and should look like a verb, whereas it bears no resemblance to one in either Ngarrindjeri or Kaurna, which take - $u n$ and -ndi endings respectively. The reference to a stage of initiation, as found in T\&S, is a strong possibility. This practice may be associated with success in hunting or fertility rites, but there is certainly nothing in the name itself to suggest that it means 'to invoke a good harvest'.

\subsection{Kondoparinga}

An even better example is that of Kondoparinga, the name given by Governor Robe to a Hundred $^{5}$ in the Willunga area in 1846. According to Cockburn (1908:76) it is a "native word meaning "long, winding water, breeding crawfish between steep banks", a notion which by my estimation would require at least seven morphemes to encode literally. It is almost certain that Kondoparinga consists of just three morphemes, possibly kundo 'chest' + parri 'river' + -ngga 'LOC' (i.e. 'chest river place').

\subsection{Noarlunga}

Cockburn (1990:160) and Manning (1986:152) assert that Noarlunga means 'fishing place' while Praite and Tolley (1970:129) say that it means 'the place with a hill'. Praite and Tolley are obviously drawing on the fact that Ramindjeri has ngurle 'hill' and this, combined with the Kaurna suffix -ngga, results in Noarlunga.

However, it is far more likely that Noarlunga derives from Kaurna nurlo 'curvature; corner' and referred to Horseshoe Bend, on the Onkaparinga River, where the town was first established. Certainly, as we observed earlier, T\&S recognised this.

\subsection{Pattawilya}

In his earliest publication, Cockburn (1908:50) gives the meaning of Patawilya as 'cloggy, green place', an etymology that also appears in Martin (1943), though Martin gives Patawalonga as 'Aboriginal for boggy and bushy stretch with fish'. In like fashion, later, Cockburn (1984; 1990:87) claims that Pattawilya, the Indigenous name for Glenelg or Holdfast Bay, means 'swampy and bushy, with fish'. Here again, such a notion would require at least three and probably four distinct morphemes. As most root morphemes in Kaurna are disyllabic, the word pattawilya almost certainly consists of just two morphemes. Furthermore, no part of the word bears any resemblance to kuya 'fish'. The name is in fact transparently composed of patta 'a species of gum tree' (possibly the swamp gum) and wilya 'foliage; young branches; brushwood'. So 'swampy and bushy, with fish' is fanciful to say the least, as a supposed literal meaning of Pattawilya.

5 'Hundred' means a major division of land, the purpose of which is to provide unique identities for properties in conjunction with the section numbers. The actual size varies from one to another (Bill Watt pers. comm.). 


\subsection{Cowandilla}

All three sources (Praite \& Tolley 1970:32; Manning 1986:48; and Cockburn 1990:52) state that Cowandilla means 'water', or in Manning's case 'locality of the waters'. Further, Manning records the name as 'kaunenna-dlla'. While Manning does not specifically name Webb as the source, it is fairly clear that the latter is responsible for this etymology. Webb (1936-37:302) says that

certain waterholes near Glenelg were called 'Kauwenna'. 'Kauwe' is water. 'Kauwenna' means the Waters. 'Kauwenna-dlla', the name of the locality survives in the pretty placename 'Cowandilla', which means the locality of the waters.

Now, 'locality of the waters' should appear as kauwe + nna + illa 'water+PL+LOC' resulting in kauwinnilla. It is actually questionable whether a plural morpheme would appear in such a Kaurna word. Kauwingga may be more likely. In any event, there is no way of accounting for the presence of the ' $d$ ' in such an etymology. Therefore, this etymology is most unlikely.

Tindale (card files) also claims that Cowandilla means literally 'in the waters' and breaks down the word as kauwe 'water' $+a n$ 'PL' + til:a 'in' or 'among', though it is unclear where he gets til: $a$ from.

An alternative etymology is far more likely. The word for 'north' is kauanda and upon attaching the location suffix -illa, as it is a trisyllabic root, the result would be kauandilla 'in the north', corresponding exactly to the form of the name as it is known today. This contrasts with Patpangga, the name for Rapid Bay, which means 'in the south'.

In this case, I am suggesting that all the numerous popular accounts are false. Undoubtedly there were springs in the area, and Cowandilla may indeed have been the rightful name for one or more of these springs, but I assert that it did not literally mean 'water' or 'spring' or anything related to water. Kauwe 'water' was one of the few Kaurna words with which many colonists would have been familiar, and I would suggest that people jumped to conclusions.

\subsection{Uraidla}

It was noted earlier that Uraidla was one of just two Kaurna placenames for which nineteenthcentury sources provided a meaning. It is derived from yurridla 'ear-DUAL'. However, Webb writing in the Advertiser on 3 December 1927 claimed that it meant 'place of the ear' and that -dlla was the location suffix. Here Webb is confused. The location suffix on trisyllabic roots is -(i)lla and the 'd' cannot be accounted for using this etymology. Cockburn (1990:225) also suggests that, on the basis of T\&S, Uraidla is derived from yurre 'ear' + idla 'whelp'. Further he quotes a letter from Thomas Playford written in 1872 claiming that Uraidla meant 'spring, or source of many waters'.

\footnotetext{
It is not clear what the point of reference is for Patpangga and Kauandilla. At the Indigenous Placenames Colloquium on 8 April 2000, Jane Simpson suggested that these places may be relative to the country of the Kaurna men who served as the main informants for T\&S, Wyatt and others. Mullawirraburka's and Ityamaiitpinna's country lay roughly mid-way between these two locations. However, Patpangga is a Kaurna name which was clearly in use before the arrival of the colonists, as it was used by Kalloongoo in her interview with George Augustus Robinson in June 1837 and she had been kidnapped from the Rapid BayYankalilla area many years before that (see Amery 1996).
} 


\subsection{Piccadilly}

Cockburn gives three different accounts of Piccadilly having been named by different people after Piccadilly in London:

1. It was named by Mrs John Young after her birthplace in London in about 1853.

2. It was named in about 1862 or 1863 by Mary Johns, an English cook who worked for Arthur Hardy, one of the earliest residents of the district.

3. The gardener at Piccadilly, H. Curtis, disputed the second account and asserted that Samuel Tonkinson bestowed the name.

Who should we believe? The second possibility given by Cockburn is accompanied by a lengthy story contained in a letter published in a newspaper in 1928:

Mrs Caulfield Barton, daughter of Arthur Hardy, one of the earliest residents of Mount Lofty district wrote to the Advertiser: 'My mother had for us an English nurse, Miss Everitt and when we were living at Mount Lofty House - about 1862 or 1863 - she also had a young English cook named Mary Johns. Right and lively girl, and as my father's house was at the time the only one on Mount Lofty proper, it was naturally dull for the maid. One day she said to Miss Everett, "Come for a walk" and on going out Miss Everett asked, "Where shall we go?" "Let's take a walk down Piccadilly", said Mary Johns, and they followed the track to the bottom of the gully, where at the time there were only charcoal burners and no houses at all. So Miss Everett told my mother of the joke Mary had made and the name stuck to it - in fun at first - and afterwards it was accepted by everyone. The very fact of its unlikeness to London Piccadilly was the cause of its getting the name.' (in Cockburn 1990:175)

I have no reason to doubt that Mary Johns and Miss Everett did go for a walk and that the conversation as quoted in the letter did take place. But why would Mary Johns have said 'Let's take a walk down Piccadilly'? She may well have been familiar with the Indigenous name of the place, which reminded her of Piccadilly. After all, nothing else about the location bore the least resemblance to Piccadilly in London as the writer of the letter points out.

In fact, Manning (1986:168) tells us that the name derives from piccoddla 'the locality of the eyebrow'. This is confirmed by T\&S who give piko 'eyebrow'. The dual form would be pikodla (i.e. 'two eyebrows'), just as Uraidla or yurreidla is the 'two ears'.

I would suggest that a number of patently English names were given to localities because they bore resemblances like this to the Indigenous name. Another good example of this is the town of Gawler, named after South Australia's second governor Colonel George Gawler. The Kaurna name is recorded as Kaleeya or Kaleteeya. The close resemblance is probably not a matter of sheer coincidence. It could also be that the recorded Kaurna names were a Kaurna pronunciation or corruption of Gawler.

There are even more striking cases of conflicting etymologies than these. Consider the following examples:

\subsection{Yankalilla}

Yankalilla has been the subject of much discussion and fantasy as to its origins. Some observers have even suggested that Yankalilla is not an Aboriginal word. Note Cockburn's entry: 
Yankalilla has always been a puzzle in nomenclature and probably always will be. Undoubtedly it is an Aboriginal word, but although it is known that the terminal 'illa' indicates locality, either at, on, or near, no satisfactory record of the meaning of the prefix has ever been established. The orthography of the word went through an extraordinary range of variations before settling down to its present form.

Teichelmann and Schïrmann's Vocabulary, published in 1840, gave it as Yankalya-illa, but quite a dozen different spellings could be quoted. The first time that Colonel Light mentioned the name in his journal, he made it Yankalilla, but on one of his plans he wrote it Yanky-lilly, together with Yanky Point. This gave rise to the diehard theory that the appellative was derived from the circumstance that an American whaler, who had a daughter called Lily, used to frequent the coast near Yankalilla; a variation of the story being, that an American whaler known as the Lilly was wrecked thereabouts. But there are plenty of Aboriginal words with the suffix '-illa' - for example Tunkalilla district and beach in the same region as Yankalilla. In one of the dark recesses at the gorge of the later $<$ sic $>$ place there is a never-failing spring of water and the precise locality was a favourite camping place of the natives. It is highly probably [sic] that the name has reference to that fact. (Cockburn 1990:247)

Governor Hindmarsh, in a dispatch to Angas in 1837, wrote:

There is a spot near Cape Jervis with one of the sweetest sounding names I ever heard, pronounced Yoongalilla, which, like all their other words, is extremely liquid in its sound. Colonel Light, I am sorry to say, in his letter to the Commissioners, has adopted the Kangaroo Island Whalers cognomen of Yanky-lilly. I thought it was some place that had been frequented by the American Whalers. (quoted in Williams 1985:6)

Even more compelling is the fact that Yankalilla is referred to in an interview given in 1837 by Sarah or Kalloongoo, a Kaurna woman kidnapped by sealers and taken to Kangaroo Island. Kalloongoo was kidnapped most likely in the early 1820 s, taken to Kangaroo Island where she remained for some time, then taken to Portland and later to Bass Strait (see Amery 1996). She told George Augustus Robinson on 2 June 1837 that she had been kidnapped from the Yankalilla-Rapid Bay area:

Said the country where she came from was called BAT.BUN.GER [Patpangga = Rapid Bay] YANG.GAL.LALE.LAR [Yankalilla]. It is situate [sic] at the west point of St Vincents Gulf. (Plomley 1987:446)

So, if the origins of Yankalilla are from English, it must have been very early, prior to the establishment of the colony of South Australia, and the name must have been known, remembered and used by a Kaurna woman kidnapped from there many years previous. This is most unlikely. Thus the non-Aboriginal origins of Yankalilla can be readily dismissed.

However, that is not the end of the matter, for we have conflicting Indigenous etymologies for the word, including two totally different explanations put forward by the same author. On the one hand, Tindale provides a Kaurna etymology for Yankalilla which appeals to the well-known Tjilbruke Dreaming story. Manning (1986:237) writes:

A difference of opinion regarding the origin of the name [Yankalilla] prompted a spate of letters to the Register, each writer giving different versions. (see 10,13,16, 17, 20 \& 25 Feb 1928). Professor N.B. Tindale says 'it is derived from the Aboriginal word jankalan, meaning "falling", from an incident in the myth of Tjilbruke, whose sister's [sic] mummified body began to fall into pieces here, as he was carrying it from Brighton to Cape Jervis for burial'.

However, Tindale's Kaurna card file, held by the South Australian Museum, provides an entirely different etymology for the name as follows: 
Jangkaljil:a 'Yankalilla' Lit. 'Upon the hill' Deriv. ['jangkalja] 'hill' + [íl:a] 'at or upon' Jangkaljawangk 'Yankalilla' Deriv: ['jangkalja] 'hill' + ['wangk] 'upon'

This etymology is based on Ramindjeri and Kaurna. Meyer (1843) lists the Ramindjeri word yangaiake 'hill', which Tindale has combined with the Kaurna locative suffix -illa.

R.F. Williams (1985) in his volume on the local history of the Yankalilla area has made even more far-reaching blunders in confusing Kaurna with Ramindjeri. He writes:

A mission was established in the territory of the Ramindjeri people at Encounter Bay. Teaching commenced and a study of the language, sufficient to publish a vocabulary in the native tongue, was made by 1840 .

The missionaries gave the locality name as Yankalya-illa. The vocabulary records that nganka is Ramindjeri for woman, alya for tragedy and illa for place terminal. It is not a far step from Nganka-alya-illa to Yankalya-illa. (Williams 1985:6-7)

Unfortunately this statement is wrong in several details. The published vocabulary Williams refers to is that of Teichelmann and Schürmann (1840). Meyer's Ramindjeri vocabulary was not published till 1843. The Ramindjeri word for 'woman' is mimine (Meyer 1843:80), a word still used today. No such word nganka is listed by Meyer. Williams must have mis-transcribed the Kaurna word ngangki 'woman'. Meyer (1843:50) lists Yangkallyaw-angk for Yangkalilla. I contacted Roy Williams by phone in 1995. He was unable to locate his sources and seemed to fail to understand that Ramindjeri and Kaurna were different languages. Unfortunately, a Royal Geographic Society publication has perpetuated Williams' errors:

The meaning of this word is still a puzzle. Light wrote of it in its present form, but later referred to it as Yanky-lilly.

Missionaries at Encounter Bay in 1849 who published a vocabulary in the native tongue, in 1840 referred to it as Yanky-aly-illa. Ngangka is Ramindjari for woman, alya for tragedy and illa for place, hence Nganga-alya-illa to Yank-aly-illa. (RGSASA 1989:12-13)

Now Teichelmann and Schürmann $(1840: 21,76)$ clearly identify Yankalilla as a Kaurna name. It is given as an example of the location suffix -illa affixed to trisyllabic roots 'Yangkalyilla, in Yangkalya'. It derives from yernka-, the root of the verb yernkandi 'to hang down, on; to join; impart; infect' + -lya 'CONTINUOUS' + -illa 'LOC'. Thus it translates literally as 'the place where [it] kept falling apart', a meaning entirely consistent with that given by Manning above on the basis of information supplied by Norman Tindale. Yankalilla might be thought of as 'the place of the fallen bits'. Tindale's other etymology which relates Yankalilla to a Ngarrindjeri word is unlikely to be the 'true' etymology, though it was undoubtedly believed to be so by Tindale's Ngarrindjeri informants, such as Milerum.

\subsection{Yatala}

Yatala is another clear example where Tindale seems to have gone astray. According to Tindale's Card File:

'Jatala 'Yatala; Dry Creek'

Probably post-contact name arising from the presence of a white man's prison. The name seems to be linked with the verb ['jat:un] 'to steal'. 
However, Tindale's ['jat:un] is clearly a Ngarrindjeri word. Meyer (1843) lists yart-in 'stretching out the hand to receive' while Taplin (1879:136) gives yartin 'reaching out the hand to receive'. Yatala is a placename that has been used by non-Aboriginal people since 1836. In 1846 the Hundred of Yatala was proclaimed, long before the establishment of the Yatala Labour Prison, which was known as the Stockade of Dry Creek in 1854. The prison was re-named Yatala Labour Prison some time between 1854 and 1860 (phone enquiry, Yatala Labour Prison 21 November 1997). Thus in this case, Tindale's etymology is clearly falsifiable. The prison authorities now understand Yatala to mean 'meeting place' or 'by the water'.

Yatala most likely derives from yertalla 'water running by the side of a river; inundation; cascade'. As Manning (1986:238) observes 'in winter when water flowed from the hills, over the plains, the Dry Creek area became a morass'.

\subsection{Kangarilla}

Kangarilla almost certainly derives from kanggari- 'to bring forth' + -(i)lla 'LOC'. According to Manning (1986:100), Tindale says 'it is derived from the Aboriginal word Kanggarila, which may mean birthplace', but we have no information about the context. Perhaps it referred to the encampment of a shepherd who first moved into the area. Note that T\&S give sheepi kanggallanggalla 'a shepherd', derived from kanggandi 'to lead; conduct; accompany; to bear a child "bring forth".

Cockburn (1908:76) claims that Kangarilla is derived from Kangooarinilla, "native for "place where sheep mother sits down" - "kanga", a ewe with lamb; "illa" the place of sitting' and notes that it was formerly called Eyre's Flat, on account of it once being the property of Edward John Eyre, the explorer. In Cockburn $(1984 ; 1990: 112)$ this etymology has been replaced by a reference to Dutton's (1846) South Australia and its Mines which claims that Kangarilla is derived from Kangowirranilla, meaning the 'place for kangaroo and water'. However, Cockburn himself thinks that it is 'more likely to be kangaroo and timber', no doubt having noticed the presence of wirra 'forest, bush' in the word.

However, Manning also cites an entirely different etymology to both his own and Cockburn's as follows (1986: 100):

In Kangarilla Historical Records the compiler says - 'the Reverend Gordon Rowe of the Aborigines Friends' Association obtained the following information from Mr David Unaipon, an eighty-two year old full blood member of the Tailem Bend tribe. His definition of the meaning of the origin of the name is - "Kang means two; Ra'mulia means outflow or water flowing ..." When first approached on the matter Mr Unaipon at once asked if there were two waterholes. Upon enquiry it was found that there were two...'

This entry is extremely revealing of the ways in which etymologies arise, particularly many of those in Tindale's materials (1987; Card files; assorted papers) which were mostly obtained from Ngarrindjeri sources. In this case, Kangarilla was not Unaipon's country. Having been asked about it, of course he tries to make sense of the name in his own language and comes up with kang + ra'mulia. First, Kangra'mulia is not particularly close phonetically to Kangarilla. In fact, it is difficult to see how the two forms could refer to the same name. Further, we have seen that Kangarilla already has a perfectly good etymology in Kaurna, the language of the territory of the place itself. This Kaurna etymology is based on morphology which conforms perfectly to expected Kaurna patterns. Unaipon's suggestion is clearly a false folk etymology. 


\subsection{Willunga}

The town of Willunga, laid out in 1839 , is another interesting case. There are in fact three competing etymologies for Willunga, all from within the Kaurna language, and all of them plausible.

1. Willunga is from willa 'dust' + -ngga 'LOC'. Williams (1840) records wil-lah 'dust'.

2. Willunga is from wilya 'foliage' + -ngga 'LOC'. This is certainly the etymology that the Willunga Council ascribes to. Manning (1986) says it means 'a place of green trees'.

3. Willunga is from willi 'the chest of a kangaroo or other animal' + -ngga 'LOC'. This is the etymology put forward by Webb when he links the place with Uraidla and other locations referring to parts of a giant kangaroo laid out across the landscape.

The first etymology is in fact the most likely of the three, though perhaps least favoured. $\mathrm{T} \& \mathrm{~S}$ record the name as Willa-ngga, though they do not record willa in their vocabulary. If it had been derived from wilya or willi, most likely they would have recorded the name as Wilya-ngga or Willi-ngga. Perhaps Willa-ngga means something entirely different. There are four distinct laterals (or ' 1 ' sounds) in Kaurna. T\&S often wrote three of these, namely an interdental [lh], alveolar [1] and retroflex [rl], with a double '1l'. Nor did Williams distinguish between these three ' 1 ' sounds. So T\&S's Willa-ngga may bear no relationship to Williams' wil-lah 'dust'.

\subsection{Warriparri}

Similarly, three meanings for Warriparri, the Sturt River, are to be found:

1. According to Cockburn (1990:209) Warriparri means a 'creek fringed with trees'. No morphological analysis is suggested however.

2. Webb (1936-37:308) claims that Warriparri means 'the throat river' and suggests that it is derived from warra 'throat' and parri 'river'. The existence of the suburb Warradale in the vicinity, which itself was named after a property in the area, lends some credence to this suggestion.

3. Most sources say that Warriparri means 'windy river' and is thus derived from warri 'wind'. This is entirely consistent with T\&S's spelling of the word and with other historical sources: War-rey par-rey (Williams 1840) and Wari pari (Black 1920). They all agree on the vowel being ' $i$ ' rather than ' $a$ '. Thus this is the most likely etymology. This is also the meaning favoured by literature produced by the Kaurna Aboriginal Community and Heritage Association (KACHA Inc.) and the Marion City Council in relation to the Warriparinga heritage site and planned Interpretive Centre (Warriparinga brochure, October 1997). 


\section{BODY PARTS OF THE GIANT KANGAROO}

Noel Augustin Webb spent considerable effort puzzling over Kaurna placenames. He published an article 'The Place Names of the Adelaide Tribe' for several years running. Webb had refined and expanded this article with successive publications.

Webb suggests that no less than 11 Kaurna names, some of which have been discussed already, are related to body parts of a giant kangaroo stretching from Gumeracha, north-east of Adelaide, to Encounter Bay and Kangaroo Island. According to Webb (1936-37), these parts are as follows:

$\begin{array}{ll}\text { Uraidla } & \text { yurridla }=\text { yurre 'ear' + dla 'DUAL' (i.e. two ears) } \\ \text { Piccadilly } & \text { pikodla }=\text { piko 'eyebrow' +-dla 'DUAL' (i.e. two eyebrows) } \\ \text { Gumeracha } & \text { ngarrumuka 'brain' } \\ \text { Mudlangga (Le Fevre Peninsula) } & \text { mudla 'nose' + -ngga 'LOC' } \\ \text { Warripari (Sturt River) } & \text { warra 'throat' + parri 'river' } \\ \text { Marino } & \text { marra 'hand' + -nna 'PL' (i.e. paws) } \\ \text { Willunga } & \text { willi 'chest' + -ngga 'LOC' } \\ \text { Kundoparinga (near Willunga) } & \text { kundo 'chest' + parri 'river' +-ngga 'LOC' } \\ \text { Murtapari (Inman River) } & \text { murta 'excrement' + parri 'river' } \\ \text { Yerltoworti (Hindmarsh River) } & \text { yerta 'land' + worti 'tail' } \\ \text { Karta (Kangaroo Island) } & \text { karta 'lap' }\end{array}$




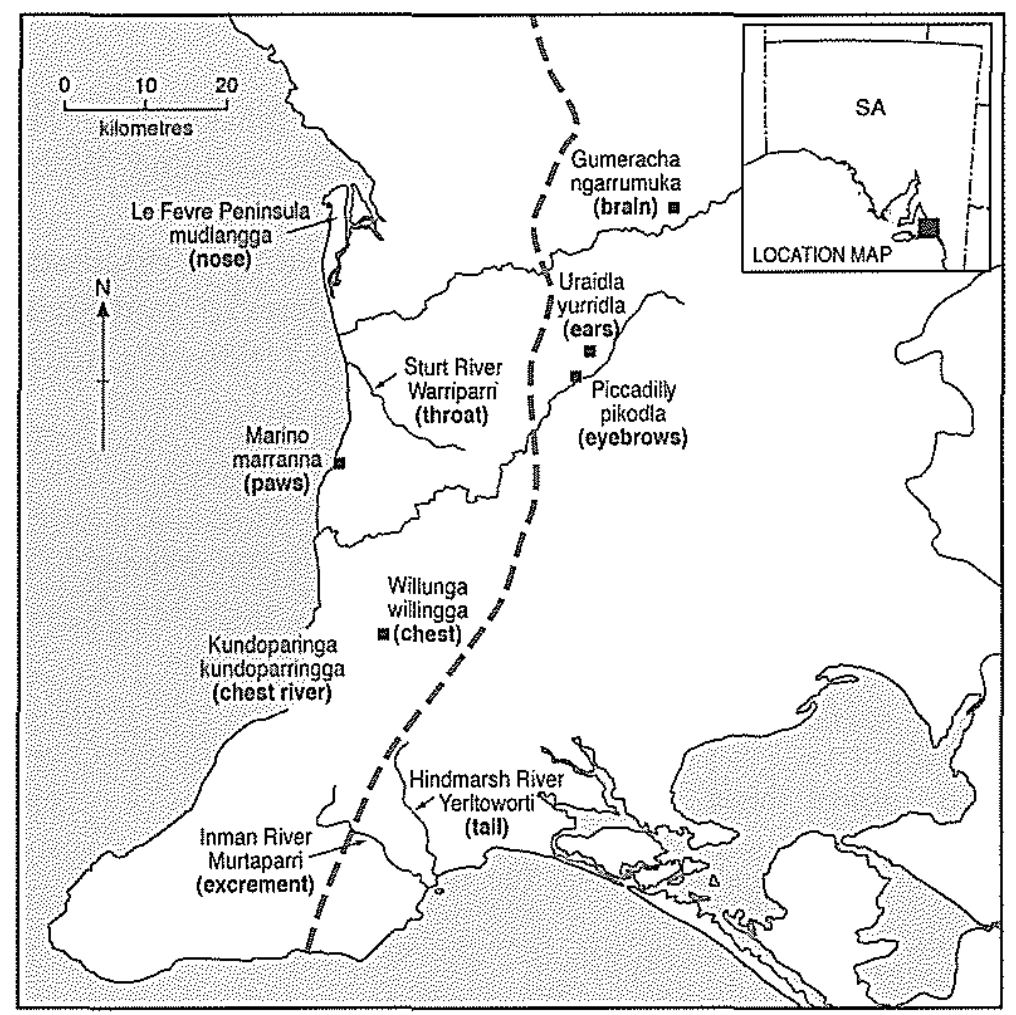

Map 2: Placenames related to body parts of a kangaroo (according to Webb 1936)

As discussed above, there is little doubt that the two peaks, Mount Lofty and Mount Bonython named Yurreidla 'two ears', are likened to the ears of this being. There is also a strong possibility that Piccadilly, an Anglicisation of pikodla 'two eyebrows' is a part of the same being, though Simpson (1995) suggests that it might derive from piko+rti+dla 'eyebrow-without-DUAL'. Mudlangga 'Le Fevre Peninsula' is undoubtedly 'nose place', but whether or not it refers to the nose of this same kangaroo being is another matter. The word for 'nose' is used by other Australian languages to refer to peninsulas, as in Yolngu Matha ngurru 'nose; tip; front; peninsula; cape; point (of land, spear)' (Zorc 1986:233). Several of the locations suggested by Webb, while plausible, have other competing etymologies. Willunga and Warriparri have been discussed above. Webb's etymology for Marino as maranna 'hands' is suspect. If the name did in fact refer to the front paws, we would expect mararla with the dual suffix. A hind leg is probably referred to as tidna 'foot' rather than marra 'hand'. According to Cockburn (1990:137), Marino was named after San Marino, while Praite and Tolley (1970:109) say that Marino was 'originally Marina, which is the Italian word for "seashore". It is also highly unlikely that yerlto in Yerltoworti as transcribed by $T \& S$ is a variant or mis-transcription of yerta 'land'. T\&S are generally consistent in their transcriptions. Had they meant yerta, they would have written it as yerta. Deriving Gumeracha from ngarrumuka 'brain' is also perhaps drawing a long bow. It would involve metathesis or transposition of sounds within the word (i.e. swapping of the ' $r$ ' and ' $m$ '), transcription of the initial velar nasal with ' $\mathrm{g}$ ' and the transcription of the high back vowel as 'er' and ' $a$ '. All these are possible, but in the light of other questionable etymologies this one must be suspect too. It would appear that Webb did have an opportunity to meet with Ivaritji, and it is possible that some of these etymologies came from her. However, Webb does not 
clarify the source of his etymologies and one is left wondering whether Webb himself is extending a metaphor and a naming process well beyond its actual application.

It is evident from some of the above examples and the following that Webb does not have a good grasp of Kaurna morphology. He provides these two false etymologies elsewhere in his article:

$\begin{array}{ll}\text { Cowandilla } & \text { from katwennadlla }=\text { kauwe 'water' }+-n n a \text { 'PL' }+ \text {-dlla 'LOC' }<\mathrm{Sic}> \\ & <\mathrm{cf} \text { kawandilla }=\text { kawanda 'north' + -illa 'LOC'> } \\ \text { Tarndanyangga } & \text { from tarndannangga }=\text { tarnda 'red kangaroo' + -nna 'PL' + -ngga 'LOC' } \\ & <\mathrm{cf} \text { tarndanyangga }=\text { tarnda 'red kangaroo' + kanya 'rock' + -ngga 'LOC'> }\end{array}$

So, on linguistic grounds we are forced to question the validity of some of his etymologies, in the absence of the identification of his sources and further information. However, the etymologies suggested by Webb seem to have gained some acceptance within the Kaurna community and make sense to them.

\section{COWILLA - BEWARE OF JUMPING TO CONCLUSIONS}

Several years ago I saw the name Cowilla at the Port Elliot show. We might be tempted to suggest that the name means 'water place', derived from kauwe 'water' + -illa 'LOC'. A basic word in Kaurna and other languages to the north is kauwe. It appears in many placenames in the Flinders Ranges, mid-north and Yorke Peninsula, whilst -illa is found in a number of placenames nearby (such as Yankalilla, Tunkalilla and Kangarilla). However, -illa is suffixed only to trisyllabic roots. If the name were indeed 'water place', then we would expect Kauwingga (or Cowinga or some other variant spelling). Cowilla is in fact the name of a dairy farm, and for a while I thought that it might derive from English 'cow' with the Kaurna location suffix attached, in the same way that the names of the Adelaide suburbs of Glenunga, Glenalta, Warradale and Paraville have been formed. Upon making enquiries, however, it turns out that the dairy stud is located at Mannum, a considerable distance from Kaurna country adjacent to Cowirra Swamp (meaning unknown). The name Cowirra was already in use, so the owner of the dairy substituted $l l$ 's for the $r r$ 's because they sounded all right (Steven Vivienne pers. comm., 6 April 2000). So the name is not related to a Kaurna word at all.

\section{SUMMARY OF LINGUISTIC PRINCIPLES AND METHODS FOR WEEDING OUT SPURIOUS ETYMOLOGIES}

In the examples above, I have demonstrated that linguistic principles and a detailed knowledge of the Kaurna language can be used to call into question and exclude certain etymologies put forward in the literature for placenames on the Adelaide Plains. The general principles outlined here can be applied to other languages, though of course the specifics will vary in accordance with the particular language.

For any given name, the following procedures can be applied: 
1. Assemble all known spelling variants and meanings, together with their sources.

2. How reliable are the respective sources? What other kinds of errors did the writer make? (e.g. Webb; Tindale) What were the ultimate sources of the information? How well did these sources know the country? (e.g. Ngarrindjeri men Unaipon and Milerum talking about Kaurna places)

3. Identify known morphemes (e.g. -ngga 'LOC'; -(i)lla 'LOC'; -rla -dla 'DUAL'; parri 'river'; wirra 'forest' etc.) often found in placenames of the area.

4. Check for similar forms in recognised sources (e.g. T\&S; Wyatt etc.).

5. Calculate the number of morphemes required to encode the notion conveyed in the English gloss and check against the likely number of morphemes present in the Indigenous word. In Kaurna there are very few monosyllabic roots. Most are disyllabic, while some are trisyllabic. So a word like Myponga (Maitpangga) is likely to consist of a disyllabic root maitpa plus the location suffix.

6. Identify morphophonemic irregularities. For example, -(i)lla only ever appears on trisyllabic roots. A final la syllable on a disyllabic root is more likely to be the dual suffix -rla -dla 'DUAL' than the location suffix -(i)lla 'LOC'.

7. Check for semantic consistency. For example, the paws of a kangaroo should appear as marrarla 'hand-DUAL' rather than marranna 'hand-PL' since the hind feet are referred to as tidna 'foot'.

8. Beware of meanings like 'many springs', 'plenty of water' or 'good water' etc. in the absence of identifiable words for water (e.g. pudna 'spring', kauwe 'water', parri 'river'). There is a strong possibility that such a word may have indeed been the name of a spring, but did not literally mean 'spring' etc.

\section{CONCLUSIONS}

In this short paper I have discussed a range of Kaurna placenames where linguistics can be brought to bear, in the absence of speakers of the language, to question and weed out certain etymologies recorded in the literature. A knowledge of Kaurna morphology and phonology helps to narrow down allowable possibilities. In the final analysis, however, in most cases we simply cannot be certain of the 'true' etymology.

\section{REFERENCES}

Amery, Rob, 1996, Kaurna in Tasmania: a case of mistaken identity. Aboriginal History 20: $24-50$.

Black, J.M., 1920, Vocabularies of four South Australian languages, Adelaide, Narrunga, Kukata, and Narrinyeri, with special reference to their speech sounds. Transactions of the Royal Society of South Australia 44:76-93.

Cockburn, Rodney, 1908, Nomenclature of South Australia. Adelaide: W.K. Thomas \& Co. 
- 1990, South Australia. What's in a name? Adelaide: Axiom Publishing (Revised edition. First published 1984).

Dutton, Francis, 1846, South Australia and its Mines. London: T. \& W. Boone.

Hercus, Luise, 1992, Nukunu Dictionary. Canberra: the author.

Manning, Geoffrey H., 1986, The Romance of Place Names of South Australia. Adelaide: the author; Gillingham Printers.

Martin, A.E., 1943, Twelve Hundred and More Place Names in South Australia, Western Australia and the Northern Territory. Sydney: NSW Bookstall Co.

Meyer, H.A.E., 1843, Vocabulary of the Language Spoken by the Aborigines of the Southern and Eastern Portions of the Settled Districts of South Australia. Adelaide: James Allen.

Moorhouse, Matthew, 1846, Vocabulary and Outline of the Grammatical Structure of the Murray River Language. Adelaide: printed by Andrew Murray.

Piesse, Louis, 1840, Letter to South Australian Colonist, July 1840.

Plomley, N.J.B., ed., 1987, Weep in Silence: a history of the Flinders Island Aboriginal settlement. Hobart: Blubber Head Press.

Praite, R. and J.C. Tolley, 1970, Place Names of South Australia. Adelaide, Sydney, Melbourne, Brisbane and Perth: Rigby.

Royal Geographical Society of Australasia (SA Branch), 1989, Captain Collet Barker Field Day. Adelaide: RGSASA.

Simpson, Jane, 1995, CUP Adelaide placenames reduced electronic data file (last updated 11 April 1995).

Taplin, George, 1879, The Folklore, Manners, Customs, and Languages of the South Australian Aborigines. Adelaide: Government Printer.

Teichelmann, C.G. and C.W. Schürmann, 1840, Outlines of a Grammar, Vocabulary, and Phraseology, of the Aboriginal Language of South Australia, Spoken by the Natives in and for Some Distance around Adelaide. Adelaide: published by the authors at the native location. Facsimile edition 1962, State Library of South Australia. Facsimile edition 1982, Tjintu Books, Adelaide. A copy annotated by Teichelmann was sent to Grey in 1858 and is held in the Sir George Grey Collection, South African Public Library, Cape Town.

Tindale, Norman B., [Assorted Papers] held in the Tindale Collection, Anthropology Section, South Australian Museum, Adelaide.

- Kaurna place names card file held in the Anthropology Section, South Australian Museum, Adelaide.

- 1987, The wanderings of Tjirbruki: a tale of the Kaurna people of Adelaide. Records of the South Australian Museum, vol. 20, May 1987:5-13.

Webb, Noel Augustin, 1936-37, Place names of the Adelaide tribe. In Municipal Year Book, City of Adelaide, 302-310. Adelaide: The Advertiser.

Williams, Roy F., 1985, To Find the Way: Yankalilla and district 1836-1986. Yankalilla and District Historical Society Inc., South Australia. 
Williams, William, 1840, The language of the natives of South Australia. The South Australian Colonist 1(19):295-296.

Wyatt, William, 1879, Some account of the manners and superstitions of the Adelaide and Encounter Bay tribes. In J.D. Woods, ed., The Native Tribes of South Australia, 157-181. Adelaide: Government Printer. (Original manuscript with corrections in BSL Special Collection)

Zorc, David, 1986, Yolngu-Matha Dictionary. Batchelor, NT: School of Australian Linguistics. 